\title{
Species of Neosilba (Diptera: Lonchaeidae) recorded in citrus-producing region in the state of Pará, Brazil
}

\author{
Alison Pureza Castilho ${ }^{1 *}$ \\ Walkymário de Paulo Lemos ${ }^{2}$ \\ Pedro Carlos Strikis ${ }^{3}$ \\ Maria do Socorro Miranda de Sousa ${ }^{4}$ \\ Ricardo Adaime 1, 4,5 \\ ${ }^{1}$ Universidade Federal do Amapá, Programa de Pós-graduação da Rede Bionorte \\ CEP 68902-280, Macapá - AP, Brazil \\ ${ }^{2}$ Embrapa Amazônia Oriental, Belém - PA, Brazil \\ ${ }^{3}$ Independent Researcher, Americana - SP, Brazil \\ ${ }^{4}$ Universidade Federal do Amapá, Programa de Pós-graduação em Biodiversidade Tropical \\ Macapá - AP, Brazil \\ ${ }^{5}$ Embrapa Amapá, Macapá - AP, Brazil \\ * Autor para correspondência \\ alison.castilho@gmail.com
}

Submetido em 24/03/2017

Aceito para publicação em 03/07/2017

\section{Resumo}

Espécies de Neosilba (Diptera: Lonchaeidae) registradas no pólo citrícola do estado do Pará, Brasil. Este trabalho registra as espécies de Lonchaeidae obtidas de frutos de Citrus sinensis (L.) Osbeck coletados em áreas do pólo citrícola do estado do Pará, Brasil. As espécies registradas foram Neosilba glaberrima (Wiedemann), N. pendula (Bezzi, 1919) e N. zadolicha McAlpine \& Steyskal, 1982.

Palavras-chave: Amazônia; Moscas frugívoras; Neosilba glaberrima

\section{Abstract}

This work reports on the species of Lonchaeidae obtained from fruits of Citrus sinensis (L.) Osbeck collected in the citrus-producing region of the state of Pará, Brazil. The species registered were Neosilba glaberrima (Wiedemann), N. pendula (Bezzi, 1919) and N. zadolicha McAlpine \& Steyskal, 1982.

Key words: Amazon; Frugivorous flies; Neosilba glaberrima 
Diptera of the family Lonchaeidae, when in the larval stage, infest and damage fruits and vegetables. Some species are reported as primary pests in different crops in Brazil, where the genera Dasiops Rondani and Neosilba McAlpine include those species of economic importance in agriculture (UCHÔA, 2012).

In the Brazilian Amazon, studies on Lonchaeidae are still scarce, although it is known that they have a large number of native and exotic hosts, many of which are found only in wild environments (LEMOS et al., 2015). According to the database Lonchaeidae from Brazilian Amazon (PEREIRA; ADAIME, 2016), 14 species of Neosilba have already been reported for the region, where Neosilba glaberrima (Wiedemann, 1830) and N. zadolicha McAlpine \& Steyskal, 1982 are the most polyphagous and are widely distributed in this region of Brazil (STRIKIS et al., 2011; PEREIRA et al., 2016). Although studies on lance flies have increased in recent years in the region, little is known about their ecology and biology (LEMOS et al., 2015). In the state of Pará, for example, only the species $N$. glaberrima, $N$. zadolicha and $N$. pendula (Bezzi, 1919) have been previously recorded (PEREIRA; ADAIME, 2016).

Fruit crops are of importance from a social, economic and ecological perspective in Brazil (IBRAF, 2012), particularly in Pará. The municipality of Capitão Poço, located in the mesoregion of northeastern Pará, is the main producer of oranges [Citrus sinensis (L.) Osbeck, Rutaceae] in North Brazil. In this study, we carried out the first survey of species of Lonchaeidae in different orange production areas in Capitão Poço.

During the period of June to November 2012, monthly fruit samples were collected in four cultivation systems: 1) certified organic: the sampled plot was 15 ha $\left(01^{\circ} 47^{\prime} \mathrm{S}, 47^{\circ} 06^{\prime} \mathrm{W}\right)$ and had a biodiverse system with orchards of $C$. sinensis, Swietenia macrophylla King, Inga edulis Mart., Annona muricata L. and $C$. reticulata Blanco; 2) non-certified organic: the sampled plot was 4 ha $\left(01^{\circ} 48^{\prime} \mathrm{S}, 47^{\circ} 05^{\prime} \mathrm{W}\right)$, with only an orchard of $C$. sinensis; 3) conventional-organic transition: the sampled plot was 8 ha $\left(01^{\circ} 42^{\prime} \mathrm{S}, 47^{\circ} 06^{\prime} \mathrm{W}\right)$, had a biodiverse system of $C$. sinensis, S. macrophylla, Citrus $\times$ latifolia (Yu. Tanaka) and A. muricata orchards; and 4) conventional: sampled plots totaled 40 ha $\left(01^{\circ} 43^{\prime} \mathrm{S}\right.$, $47^{\circ} 06^{\prime} \mathrm{W}$ ) with only $C$. sinensis cultivated, which was managed with conventional fertilizers and conventional synthetic pesticides.

In each crop system, 120 simple samples (1 fruit) and 36 compound samples (10 fruits) were collected, totaling 1,920 fruits $(251.83 \mathrm{~kg})$. Samples were collected randomly directly from plants or soil (intact, recently fallen), where only plants with good ripening or mature fruits were considered. The procedures recommended by Silva et al. (2011) were followed for the collection of the samples in the field, processing of the samples in the laboratory and obtaining the adult insects. The Lonchaeidae specimens obtained were identified by P. C. Strikis according to the work of McAlpine and Steyskal (1982). Voucher specimens were deposited in the personal collection of the third author.

We recorded 45 specimens of Lonchaeidae $(17 \hat{\jmath}$ +28 \%), with three species identified: $N$. glaberrima $(15 \hat{\jmath}), N$. pendula $\left(1 \bigcirc^{\Uparrow}\right)$ and N. zadolicha $\left(1{ }^{\Uparrow}\right)$ (Table 1). The females recorded were identified only at the gender level. These three species had already been reported for Pará, but not in association with $C$. sinensis nor in the municipality of Capitão Poço. These findings therefore represent the first record of Lonchaeidae in the main citrus-producing region in Pará.

The cultivation systems in which the largest numbers of specimens were obtained were the certified and non-certified organic ones. In conventional cultivation, however, no lance flies were found, very likely due to the excessive use of synthetic chemical insecticides in the orchards. The number of lance flies collected varied over the sampling months, with a maximum of 20 in July (dry period) and zero in November (beginning of the first rains in the region), which may indicate that infestations by Lonchaeidae in the citrus region of Capitão Poço occur during the summer periods, thus a time requiring more attention from citrus growers.

In the state of Amapá, near Pará, the species $N$. glaberrima, N. zadolicha, N. bella Strikis \& Prado, 2006 and N. pseudozadolicha Strikis, 2011 were reported to occur in C. sinensis (PEREIRA; ADAIME, 2016). In the state of São Paulo, the largest citrus producer in Brazil, with approximately 600,000 ha cultivated with 
TABLE 1: Species of Neosilba obtained from fruits of Citrus sinensis in municipality of Capitão Poço, Pará, Brazil (JunNov, 2012).

\begin{tabular}{|c|c|c|c|c|c|c|c|c|}
\hline \multirow{2}{*}{ Cultivation systems evaluated } & \multicolumn{6}{|c|}{ Specimens Obtained/Infested Samples } & \multirow{2}{*}{$\begin{array}{l}\text { Total } \\
\widehat{\jmath}+q\end{array}$} & \multirow{2}{*}{ Species*** } \\
\hline & Jun & Jul & Aug & Sep & Oct & Nov & & \\
\hline Certified organic & $0 / 0$ & $4 / 4 * *$ & $3 / 1 * *$ & $3 / 3 * *$ & $9 / 5^{*}$ & $0 / 0$ & $9+10$ & $\begin{array}{c}\text { N. glaberrima }\left(7{ }^{\lambda}\right) \\
\text { N. pendula }\left(1{ }^{\Uparrow}\right) \\
\text { N. zadolicha }\left(1{ }^{\lambda}\right)\end{array}$ \\
\hline Non-certified organic & $2 / 2 * *$ & $8 / 1^{*}+6^{* *}$ & $3 / 2 * *$ & $2 / 1 *+1 * *$ & $0 / 0$ & $0 / 0$ & $4+11$ & N. glaberrima $\left(4{ }^{\Uparrow}\right)$ \\
\hline Conventional-organic transition & $0 / 0$ & $8 / 1 *+4 * *$ & $3 / 2 *+1 * *$ & $0 / 0$ & $0 / 0$ & $0 / 0$ & $4+7$ & N. glaberrima $\left(4 \bigcirc^{\Uparrow}\right)$ \\
\hline Conventional & $0 / 0$ & $0 / 0$ & $0 / 0$ & $0 / 0$ & $0 / 0$ & $0 / 0$ & $0+0$ & - \\
\hline Total & $2 / 2 * *$ & $20 / 2 *+14 * *$ & $9 / 2 *+4 * *$ & $5 / 1 *+4 * *$ & $9 / 5^{*}$ & $\mathbf{0} / \mathbf{0}$ & $17+28$ & - \\
\hline
\end{tabular}

*Simple sample ( 1 fruit); ** Compound sample (10 fruits); *** Only males could be identified at the species level.

C. sinensis, Raga et al. (2015) found that there were six species of Neosilba, with a predominance of N. zadolicha (65.91\%) and $N$. glaberima $(25.00 \%)$. These data differ from those obtained in the Amazon, where $N$. glaberrima represented $88.2 \%$ of the specimens obtained

We present here the results of the first survey of Neosilba species in the main citrus-producing region of northern Brazil. Further studies are necessary to elucidate the pattern of infestation by these insects in the Brazilian Amazon, mainly evaluating their potential for causing economic damage to the main commercial crops.

\section{Acknowledgments}

We thank Dr. Osvaldo Ryohey Kato, Research Scientist, Embrapa Amazônia Oriental, for technical and logistical support with the collections, and Conselho Nacional de Desenvolvimento Científico e Tecnológico (CNPq) for the Research Productivity Fellowship awarded to Walkymário de Paulo Lemos and Ricardo Adaime. Dr. A. Leyva (USA) provided English editing of the manuscript.

\section{References}

IBRAF - INSTITUTO BRASILEIRO DE FRUTAS. Produção brasileira de frutas. 2012. Disponível em: $<$ http://www.ibraf.org. br>. Acesso em: 06 jan. 2017.

LEMOS, L. N.; ADAIME, R.; COSTA-NETO, S. V.; DEUS, E. G.; JESUS-BARROS, C. R.; STRIKIS, P. C. New findings on
Lonchaeidae (Diptera: Tephritoidea) in the Brazilian Amazon. Florida Entomologist, Lutz, v. 98, n. 4, p. 1227-1237, 2015.

McALPINE, J. F.; STEYSKAL, G. C. A revision of Neosilba McAlpine with a key to the world genera of Lonchaeidae (Diptera).

The Canadian Entomologist, Ottawa, v. 114, n. 2, p. 105-137, 1982.

PEREIRA, J. F.; ADAIME, R. Lonchaeidae from Brazilian Amazon. 2016. Disponível em: <http://lonchaeidae.cpafap. embrapa.br>. Acesso em: 20 dez. 2016.

PEREIRA, J. F.; SOUSA, M. S. M.; ADAIME, R. Lonchaeidae na Amazônia brasileira. In: CONGRESSO BRASILEIRO DE ENTOMOLOGIA/CONGRESSO LATINO-AMERICANO DE ENTOMOLOGIA, XXVI/IX, 2016, Maceió. Anais... Maceió: Embrapa Tabuleiros Costeiros, 2016. Versão eletrônica.

RAGA, A.; SOUZA-FILHO, M. F.; STRIKIS, P. C.; MONTES, S. M. N. M. Lance fly (Diptera: Lonchaeidae) host plants in the State of São Paulo, Southeast Brazil. Entomotropica, Maracay, v. 30, n. 7, p. $57-68,2015$.

SILVA, R. A.; DEUS, E. G.; RAGA, A.; PEREIRA, J. D. B.; SOUZA-FILHO, M. F.; COSTA-NETO, S. V. Monitoramento de moscas-das-frutas na Amazônia: amostragem de frutos e uso de armadilhas. In: SILVA, R. A.; LEMOS, W. P.; ZUCCHI, R. A. (Ed.). Moscas-das-frutas na Amazônia brasileira: diversidade, hospedeiros e inimigos naturais. Macapá: Embrapa Amapá, 2011. p. 33-50.

STRIKIS, P. C.; DEUS, E. G.; SILVA, R. A.; PEREIRA, J. D. B.; JESUS, C. R.; MARSARO JÚNIOR, A. L. Conhecimento sobre Lonchaeidae na Amazônia brasileira. In: SILVA, R. A.; LEMOS, W. P.; ZUCCHI, R. A. (Ed.). Moscas-das-frutas na Amazônia brasileira: diversidade, hospedeiros e inimigos naturais. Macapá: Embrapa Amapá, 2011. p. 205-216.

UCHÔA, M. A. Fruit flies (Diptera: Tephritoidea): biology, host plants, natural enemies, and the implications to their natural control. In: LARRAMENDY, M. L.; SOLONESKI, S. (Ed.). Integrated pest management and pest control: current and future tactics. Rijeka: InTech, 2012. p. 271-300. 